\title{
A Study of Professional Standard for Teacher Performance of Sports Physical Education and Healthteachers of State Junior Schools
}

\author{
Erizal. $\mathrm{N}^{1}$, Adnan Fardi ${ }^{2}$, and Yendrizal ${ }^{3}$ \\ ${ }^{I}$ Health Physical Education and Recreation, Universitas Negeri Padang, West Sumatra, Indonesia \\ ${ }^{2}$ Sports Training Education, Universitas Negeri Padang, West Sumatra, Indonesia \\ ${ }^{3}$ Sports Training Education, Universitas Negeri Padang, West Sumatra, Indonesia
}

\begin{abstract}
The study is quantitative descriptive which aims to find out the competence of Sport Physical Education and Health teachers, which includes: pedagogical competence, personal competence, social competence and professional competence. The population in this study is all Sport Physical Education and Health teachers. The sample was selected by using simple random sampling. Data were analyzed using descriptive statistics to find out the values of the variables studied. The results shows that, (1) the pedagogical competence of Sport Physical Education and Health Teachers in State Junior High Schools in Padang Pariaman district is classified as "Good" with a percentage of $65.18 \%$, (2) the personal competence of Sport Physical Education and Health Teachers in State Junior High Schools in Padang Pariaman district is classified as " Good "with a percentage of $65.02 \%$, (3) the social competence of Sport Physical Education and Health Teachers in State Junior High Schools in Padang Pariaman district is classified as " Good"with a percentage of $65.50 \%$, and (4) the professional competence of Sport Physical Education and Health Teachers in State Junior High Schools in Padang Pariaman district is classified as "Good" with a percentage of $65.56 \%$.
\end{abstract}

Keywords: Pedagogic, personality, social, professional competencies

\section{INTRODUCTION}

Physical education is integral part of education system. Therefore, the implementation of physical education must be directed at the achievement of these educational goals. The purpose of physical education is not only on physical activity itself, but also to develop students' potential through physical activities. In addition, in the outline of the research plan of UniversitasNegeri Padang, it has a superior research theme namely "The development of science and technology based on local potential through quality education and character", thus it can be concluded that physical education, sport and health teachers have a very large role in the implementation of education in schools in shaping and fostering the character of the students.

According to Law No. 14 of 2005 concerning Teachers and Lecturers, article 1, paragraph 10 competencies are knowledge, skills and attitudes that must be owned and mastered by teachers and lecturers in carrying out their duties. According to Prayitno (2009: 283) competence is the ability of someone to do a unit of activity that can be immediately realized to meet certain needs. It can be understood that a competency is a series of activities with a specific material content, objectives, methods and equipment, along with the quality of their appearance. Furthermore, according to Mulyasa (2007) teacher competence is the ability of teachers in the process of providing teaching professionally so that students are able to understand the material and develop personality.

The teacher is someone who gives knowledge in schools and formal and informal institutions. According to Soenarjo (2002: 5) explained that a physical education, sport and health teachers (PJOK) is someone who has a position or profession that requires special expertise (competence) in the educational effort by giving physical education, sport and health (PJOK) lessons. Therefore, an education must have some competence, thusthey can develop and maximize the potential of students. In this case, in Law No. 14 of 2005 article 10 paragraph 1, which states the competence of the teacher referred to in article 8 includes; a, pedagogical competence, b, personality competency, c, social competence, d, professional competence. 
Pedagogic competence is a technical ability in carrying out duties as educators, instructors and mentors. Pedagogic competencies as explained by Situmorang and Winarno (2008: 23) are:

"Pedagogic competence is the ability of teachers regarding the understanding of students and the management of learning that is educational and dialogic. Substantially, this competency includes the ability to understand students, the design and implementation of learning, evaluation of learning outcomes, and the development of students to actualize the various potentials they have".

Based on the above quotations, it can be concluded that pedagogical competencies are the ability of teachers in managing the learning process to help, guide, and lead students in understanding learning materials. furthermore, personality competence, personality competence are attitudes and behaviors that must be possessed by a teacher in accordance with noble values. The personality of the teacher is very strong influence on his duties as an educator. The teacher's authority is in his personality. According to Permendiknas No.16/2007 explained, the ability in this competency standard includes five main competencies, namely:

"A) Acting in accordance with Indonesia's national religious, legal, social and cultural norms. b) Present self as honest, noble and exemplary individuals for students and the community. Present self as a person who is steady, stable, mature, wise and authoritative. d) Demonstrates work ethic, high responsibility and pride in being a teacher, and self-confidence. e) Uphold the code of ethics of the teaching profession ".

Professional competence is an ability relating to the mastery of learning material in a broad and in-depth field of study which includes mastery of the content of curriculum subject matter in schools and the scientific substance that houses the curriculum material, as well as increasing scientific insights as teachers. Mulyasa (2013: 119) that:

"Characteristics of the teachers who are judged to be professionally competent are able to develop responsibilities well, able to carry out their roles and functions well, able to work to realize the goals of school education, able to carry out their roles and functions in classroom learning" .

Social competence is related to the ability of teachers in socializing with students, fellow teachers, parents, and the surrounding community. In this context according to Wahyudi (2012: 25) a teacher should be able to:

"a) Beinclusive, act objectively and not discriminate because of consideration of gender, religion, race, physical condition, family background and socioeconomic status. b) Communicate effectively, sympathetically, and politely with fellow educators, education personnel, parents and the community. Adapt in place of duty throughout the territory of the Republic of Indonesia. d) Communicate with the professional community itself and other professions verbally and in writing or in other forms ".

Teachers are required to have good social competence in the learning process in school and in the community. this aims so that teachers can function as good social beings in their environment and in the community. so that teachers are able to establish communication and socializing well with students, fellow teachers, and parents and the surrounding community (Mulyasa, 2013: 25).

Based on the description above, the physical education teacher should have the competencies set by the above government regulations, thus they are able to develop and maximize the potential that exists in students. Early adolescence is the beginning for a child to know and start developing the potential that exists in him. Moreover, this period is the most decisive period for a student to develop his potential. Thus, physical education teachers at the junior high level are required to have good competence so that they are able to guide students in developing their potential.

Padang Pariaman district is one of the largest regencys in West Sumatra. In this regency there are 58 state junior high schools spread across 17 sub-regencys. Considering the very large number of junior high schools and spread in various sub-regencys in Padang Pariaman, the researchers were interested in conducting a study to determine the level of performance of physical education, sport and health teachers in Padang Pariaman district.

\section{METHODOLOGY}

This research method is descriptive with quantitative approach. According to Sugiyono (2012: 13) descriptive research is a research conducted with the aim to describe research variables without making comparisons with other variables. The population in the study were teachers of PJOK SMP Negeri Padang Pariaman who had civil servants and Bachelor's Academic Qualifications (S.1) and already had 52 teaching certificates for PJOK teachers to assess their performance and competencies which included four basic teacher competencies, namely Pedagogical Competencies, Personality Competencies, Social Competencies, and Professional Competencies. sampling techniques in this study used saturated sample techniques. Data collection in this study was conducted 
using a closed questionnaire. For more details, can be seen in the following table:

Table 1. Likert Scale

\begin{tabular}{|c|c|}
\hline Answer & Score \\
\hline Always & 4 \\
\hline Often & 3 \\
\hline Rarely & 2 \\
\hline Never & 1. \\
\hline
\end{tabular}

Source: Sugiyono (2014: 94)

Table 2. Presentation of Competency Achievement

\begin{tabular}{|c|c|}
\hline Interval Class & Category \\
\hline $\mathbf{8 1}-\mathbf{1 0 0}$ & Very Good \\
\hline $\mathbf{6 1 - 8 0}$ & Good \\
\hline $\mathbf{4 1 - 6 0}$ & Sufficient \\
\hline $\mathbf{2 1 - 4 0}$ & Less \\
\hline $\mathbf{0 - 2 0}$ & Very Poor \\
\hline
\end{tabular}

Source: Arikunto, (2000: 57) The
The data that had been collected wasprocessed with descriptive statistics. Data processing was performed by using the following formula:

\section{Information:}

$$
P=\frac{f}{n} x 100 \%
$$

$P \quad$ : Percentage score

$f \quad$ : Number of answers obtained

$n \quad$ : Number of respondents

\section{RESULTS AND DISCUSSION}

a. Data of Professional Standards Competence of Physical Education Teacher at SMP Negeri in Padang Priaman District

Based on the results of the study, it shows that the total score is 3804 , the average score is 73.15 , the highest value is 101 , the lowest value is 62 , and the level of achievement of respondents is $65.31 \%$.

Table 3. Frequency Data Distribution and Histograms of Professional Standards Competence of Physical Education Teacher at SMP Negeri in Padang Priaman District

\begin{tabular}{|c|c|c|c|c|}
\hline No & $\begin{array}{l}\text { Interval } \\
\text { Class }\end{array}$ & Fa & Fr & Classification \\
\hline 1 & $0-20$ & 0 & $0 \%$ & Very Poor \\
\hline 2 & $21-40$ & 0 & $0 \%$ & Less \\
\hline 3 & $41-60$ & 4 & $7.69 \%$ & Sufficient \\
\hline 4 & $61-80$ & 46 & $88.46 \%$ & Good \\
\hline 5 & $81-100$ & 2 & $3.85 \%$ & Very Good \\
\hline \multicolumn{2}{|c|}{ Amount } & $\mathbf{5 2}$ & $\mathbf{1 0 0 \%}$ & \\
\hline
\end{tabular}

Based on the table above, it can be seen that the professional standards of the performance of PJOK teachers State Junior High Schools Padang Pariaman district in the classification of "Very Poor" and "Poor" are as much as $0 \%$. In the classification of "Medium" there are as many as 4 people with a percentage of $7.69 \%$. In the classification of "Good" there as many as 88.46 people with a percentage of $46 \%$, and in the classification of "Very Good" there are as many as 2 people with a percentage of $3.85 \%$.

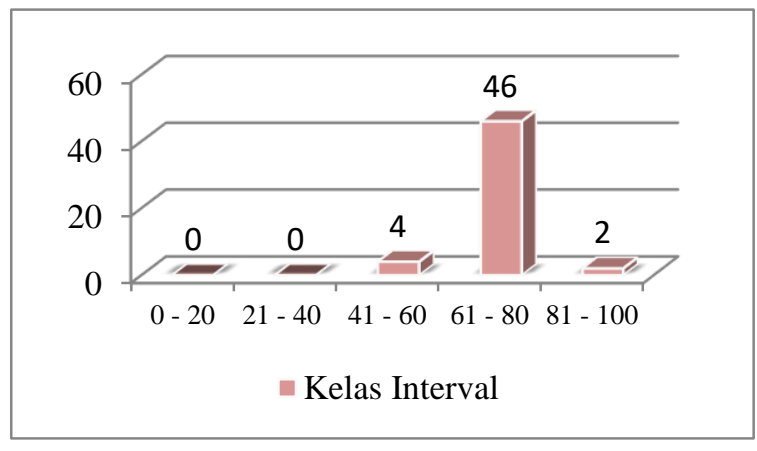

b. Pedagogical Competency Data of Physical Education Teachers at Smp Negeri in Padang Priaman District

Based on the results of this study, it shows that the total score is 1627 , the average score is 31.29 , the highest score is 44 , the lowest value is 26 , and the level of achievement of respondents $65,18 \%$. 
Table 4. Frequency Distribution of Pedagogical Competency Data of Physical Education Teachers at Smp Negeri in Padang Priaman Diistrict

\begin{tabular}{|c|c|c|c|c|}
\hline No & $\begin{array}{c}\text { Interval } \\
\text { Class }\end{array}$ & Fa & Fr & Classification \\
\hline 1 & $0-20$ & 0 & $0 \%$ & Very Poor \\
\hline 2 & $21-40$ & 0 & $0 \%$ & Less \\
\hline 3 & $41-60$ & 4 & $7 ' 69 \%$ & Sufficient \\
\hline 4 & $61-80$ & 46 & $88,46 \%$ & Good \\
\hline 5 & $81-100$ & 2 & $3,85 \%$ & Very Good \\
\hline \multicolumn{2}{|c|}{ Amount } & $\mathbf{5 2}$ & $\mathbf{1 0 0 \%}$ & \\
\hline
\end{tabular}

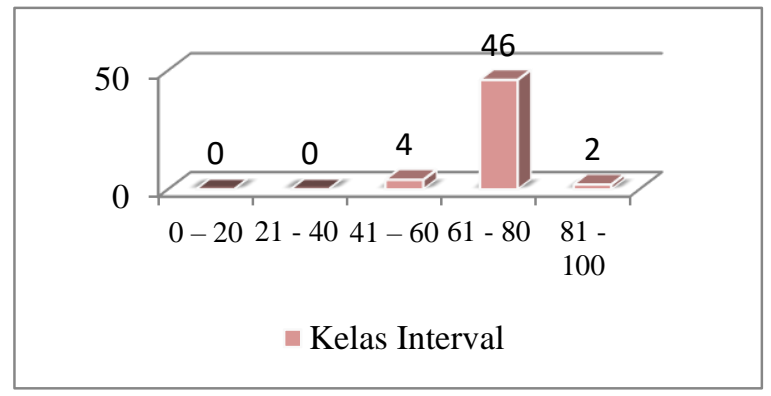

Based on the table above, it can be seen that the pedagogical competence of PJOK teachers state junior high schools Padang Pariaman in the classification of "Very Poor" and "Poor" is as much as $0 \%$. In the classification of "Medium" there are as many as 4 people with a percentage of $7.69 \%$. In the classification of "Good" there are as many as 46 people with a percentage of $88.46 \%$, and in the classification of "Very Good" there are as many as 2 people with a percentage of $3.85 \%$.

\section{c. Personality Competency Data of Physical Education Teachers at Smp Negeri in Padang Priaman District}

Based on the results of the study, it shows that the total score is 541 , the average score is 10.40 , the highest score is 14 , the lowest score is 8 , and the level of achievement of respondents is $65,02 \%$.

Table 5. Frequency Distribution and Histogram Of Personality Competency Data of Physical Education Teachers at SMP Negeri in Padang Priaman District

\begin{tabular}{|c|c|c|c|c|}
\hline No & Interval Class & Fa & Fr & Classification \\
\hline 1 & $0-20$ & 0 & $0 \%$ & Very Poor \\
\hline 2 & $21-40$ & 0 & $0 \%$ & Less \\
\hline 3 & $41-60$ & 11 & $21,15 \%$ & Sufficient \\
\hline 4 & $61-80$ & 37 & $71,15 \%$ & Good \\
\hline 5 & $81-100$ & 4 & $7,69 \%$ & Very Good \\
\hline \multicolumn{2}{|r|}{ Amount } & 52 & $100 \%$ & \\
\hline
\end{tabular}

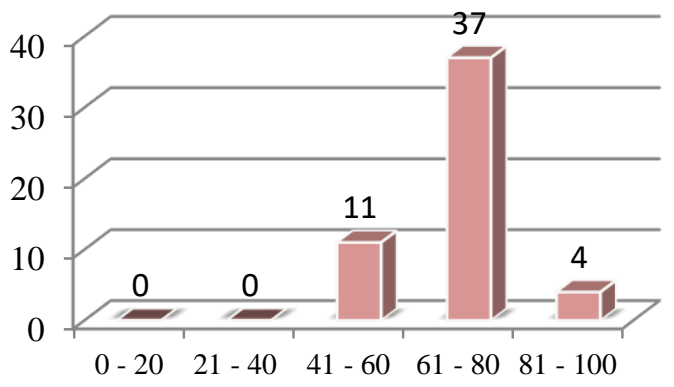

- Kelas Interval

Based on the table above, it can be seen that the personal competence of PJOK teachers in State Junior High Schools in Padang Pariaman in the classification of "Very Poor" and "Poor" is as much as $0 \%$. In the classification of "Medium" there are as many as 11 people with a percentage of $21.15 \%$. In the classification of "Good" there are as many as 37 people with a percentage of $71.15 \%$, and in the classification of "Very Good" there are as many as 4 people with a percentage of $7.69 \%$.

d. Social Competency Data of Physical Education Teachers at SMP Negeri in Padang Priaman District

Based on the research conducted, it shows that the total score is 545 , the average score is 10.48 , the highest score is 14 , the lowest score is 9 , and the level of achievement of respondents is $65,50 \%$. 
Table 6. Frequency Distribution and histogram of Social Competency Data of Physical Education Teachers at SMP Negeri in Padang Priaman District

\begin{tabular}{|c|c|c|c|c|}
\hline No & Interval Class & $\mathbf{F a}$ & $\mathbf{F r}$ & Classification \\
\hline 1 & $0-20$ & 0 & $0 \%$ & Very Poor \\
\hline 2 & $21-40$ & 0 & $0 \%$ & Less \\
\hline 3 & $41-60$ & 12 & $23,08 \%$ & Sufficient \\
\hline 4 & $61-80$ & 35 & $67,31 \%$ & Good \\
\hline 5 & $81-100$ & 5 & $9,62 \%$ & Very Good \\
\hline \multicolumn{2}{|r|}{ Amount } & 52 & $100 \%$ & \\
\hline
\end{tabular}

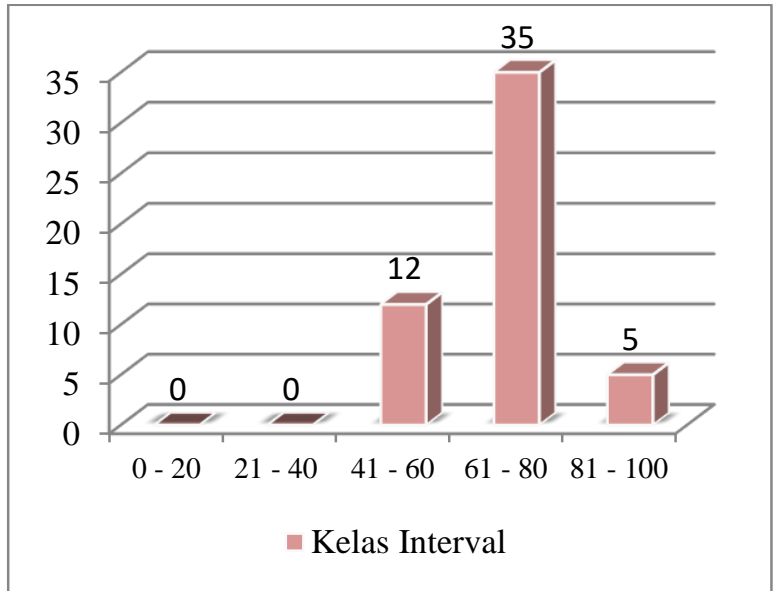

Based on the table above, it can be seen that the social competence of PJOK teachers in state junior high schools in Padang Pariaman in the classification of "Very Poor" and "Poor" is as much as 0\%. In the classification of "Medium" there are as many as 12 people with a percentage of $23.08 \%$. In the classification of "Good" there are as many as 35 people with a percentage of $67.31 \%$, and in the classification of "Very Good" there are as many as 5 people with a percentage of $9.62 \%$. e. Professional Competency Data of Physical Education Teachers at SMP Negeri in Padang Priaman District

Based on the research conducted, it shows that the total score is 1091, theaverage score is 20.98, the highest score is 29 , the lowest score is 17 , and the level of achievement of respondents is $65,56 \%$.

Table 7. Frequency Distribution and Histogram Of Professional Competency Data of Physical Education Teachers at SMP Negeri in Padang Priaman Regency

\begin{tabular}{|c|c|c|c|c|}
\hline No & Interval Class & Fa & Fr & Classification \\
\hline 1 & $0-20$ & 0 & $0 \%$ & Very Poor \\
\hline 2 & $21-40$ & 0 & $0 \%$ & Less \\
\hline 3 & $41-60$ & 9 & $17,31 \%$ & Sufficient \\
\hline 4 & $61-80$ & 40 & $76,92 \%$ & Good \\
\hline 5 & $81-100$ & 3 & $5,77 \%$ & Very Good \\
\hline \multicolumn{2}{|r|}{ Amount } & 52 & $100 \%$ & \\
\hline
\end{tabular}

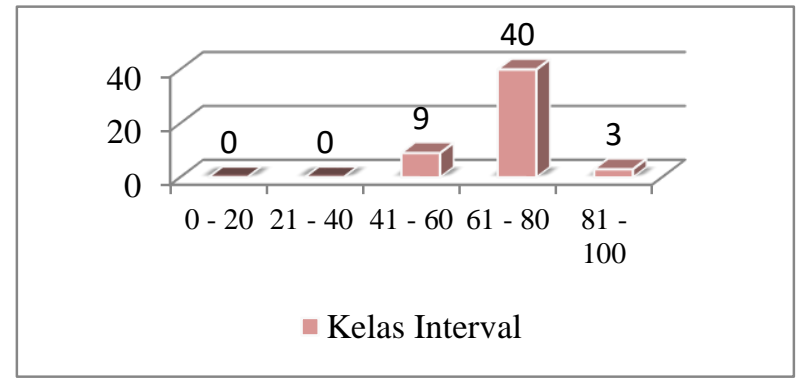

Based on the table above, it can be seen that the professional competence of PJOK teachers in state junior high schools in Kabupaten Padang Pariaman in the classification of "Very Poor" and "Poor" is as much as $0 \%$. In the classification of "Medium" there are as many as 9 people with a percentage of $17.31 \%$. In the classification of "Good" there are as many as 40 people with a percentage of $76.92 \%$, and in the classification of "Very Good" there are as many as 3 people with a percentage of $5.77 \%$.

\section{CONCLUSION}

In pedagogical competency indicators, the level of achievement of respondents obtained by Physical Education Teacher at Smp Negeri in Padang Priaman district is in the classification of "Good" with a percentage of $65.18 \%$. In the personality competency indicator, the level of achievement of respondents obtained by Physical Education Teacher at Smp Negeri in Padang Priaman district is in the "Good" classification with a percentage of $65.02 \%$. In the social competency indicator, the level of achievement of respondents obtained by Physical Education Teacher at 
Smp Negeri in Padang Priaman district is in the classification of "Good" with a percentage of $65.50 \%$. In the professional competency indicator the level of achievement of respondents obtained by Physical Education Teacher at Smp Negeri in Padang Priaman district is in the classification of "Good" with a percentage of $65.56 \%$.

\section{REFERENCES}

[1] Arikunto, Suharsimi. 2002.Prosedur Penelitian Suatu Pendekatan Praktek. Jakarta. PT. Rineka Cipta.

[2] Mulyasa, E. 2002.Manajemen Berbasis Sekolah. Bandung:PT. Remaja Rosdakarya.

[3] Prayitno. 2009.Dasar Teori dan Praktis Pendidikan. Jakarta:Grasindo.

[4] Sugiyono. 2012.Metode Penelitian Kuantitatif Kualitatif dan $R \& D$. Bandung:Alfabeta.

[5] Sugiyono. 2014.Metode Penelitian Kuantitatif Kualitatif dan $R \& D$. Bandung:Alfabeta.

[6] Soenarjo. 2002.Usaha Kesehatan Sekolah. Bandung:Remaja Rosdakarkarya.

[7] Undang-Undang Republik Indonesia No.14 tahun 2005 tentang:Guru dan Dosen. Jakarta:Pemerintah Republik Indonesia.

[8] Undang-Undang Republik Indonesia No. 20 Tahun 2003 tentang Sistem Pendidikan Nasional.

[9] Wahyudi, Imam. 2012. Panduan Lengkap Uji Sertifikasi Guru. Jakarta:PT.Prestasi PustakaryaSugiyono. 2012.

[10] Winarno.2008. Pendidikan Profesi dan Sertifikasi Pendidik. Klaten: Macanan Jaya Cemerlang. 